\title{
Corticosteroids in septic shock: What should the decision in pediatrics be?
}

\section{CoRTICOSTEROIDES NO CHOQUE SÉPtICO: QUE DECISÃO TOMAR NA PEDIATRIA?}

\author{
laura Fonseca Darmaros ${ }^{1 *}$, Artur Figueiredo Delgado², Werther Brunow de Carvalho ${ }^{3}$ \\ ${ }^{1}$ Assistant ICU Physician, Instituto da Criança, Hospital das Clínicas, Faculdade de Medicina, Universidade de São Paulo (HC-FMUSP), São Paulo, SP, Brazil \\ 2Professor, Habilitation (BR: Livre-docência), Department of Pediatrics, FMUSP, São Paulo, SP, Brazil \\ ${ }^{3}$ Full Professor of Intensive Care/Neonatology, Department of Pediatrics, FMUSP, São Paulo, SP, Brazil \\ Study conducted at Centro de Terapia Intensiva Pediátrica, Instituto da Criança, Hospital das Clínicas, Faculdade de Medicina, \\ Universidade de São Paulo (HC-FMUSP), São Paulo, SP, Brazil \\ Article received: 6/29/2016 \\ Accepted for publication: $7 / 26 / 2016$ \\ *Correspondence: \\ Instituto da Criança \\ Address: Av. Dr. Enéas de Carvalho Aguiar, 647 \\ São Paulo, SP - Brazil \\ Postal code: 05403-000 \\ laurafondar@yahoo.com.br \\ http://dx.doi.org/10.1590/1806-9282.62.06.482
}

Severe sepsis and septic shock are major global causes of morbidity and mortality in children. In this context, consensuses and guidelines were created for early and effective identification and therapeutic approach. As with adults, the guidelines for septic shock in pediatrics suggest the use of corticosteroids in cases that are refractory to vasoactive drugs. ${ }^{1}$ However, there are no pediatric clinical studies supporting the recommendation satisfactorily, and it is important to remember the fact that children are not small adults and that the steroid metabolism in both differs. ${ }^{2}$

The use of corticosteroids in septic shock has a long history in medicine and continues to generate great controversy. Its history began in the 1950s, in an attempt to treat adrenal insufficiency allegedly caused by meningococcemia in pediatric patients. ${ }^{3}$ In 1963 , a study involving adults and children showed no benefit from the use of hydrocortisone in severe infections. ${ }^{4}$ However, supported by studies by Schumer ${ }^{5}$ in the 1970s, the use of corticosteroids in high doses and for short periods of time became widespread in the treatment of sepsis until the 1980s. In 1987, in turn, two large randomized controlled studies failed to confirm its effect on mortality reduction. ${ }^{6,7}$ In 1995, two meta-analyzes (Lefering et al. and Cronin et al.) concluded there was no impact on mortality and the results could even be adverse. ${ }^{8,9}$ In the late 1990s, it was speculated that lower doses (stressdose) could reduce vasopressor doses in critically ill patients. ${ }^{10-12}$ The article that reinforced this thesis and made an immediate impact on clinical practice was published by Annane et al. ${ }^{13}$ and proposed the use of low doses over a longer period of time. This approach produced very inconsistent results in many randomized trials, which ended up concluding that this conduct not only did not reduce mortality but also could be associated with increased morbidity. ${ }^{14,15}$ The PROGRESS trial $(\mathrm{n}=8,960)^{15}$ revealed the widespread adoption of steroids in sepsis worldwide (Brazil was the country with greater use) and significant variations as to its use. In 2012, Casserly et al. ${ }^{16}$ examined the use of low doses of corticosteroids in septic shock based on data from the Surviving Sepsis Campaign and concluded that these drugs were used indiscriminately and were associated with increased mortality. Their study had the advantage of deriving from a multicenter database, and of having examined a very large population $(n=17,847)$. Recent meta-analyzes have concluded that corticosteroids appear to improve the hemodynamics of patients in shock, but without significant results on mortality. ${ }^{17}$ Currently, several studies stand out on the subject in various areas, such as the suppression of adaptive immunity ${ }^{18}$ and the resistance of tissues to stimulation by corticosteroids. ${ }^{19}$

The studies on corticosteroids in pediatric sepsis are not as scarce as before; however, there are no large controlled clinical trials on its use. Since 2005, based on a study by Markowitz et al., ${ }^{20}$ it has been discussed whether pediatric patients with septic shock would benefit from treatment with corticosteroids. Markowitz's work used data from the Pediatric Health Information System $(n=6,693)$ and showed there is no evidence to indicate bet- 
ter results in children. But the assessment was limited by lack of data related to the severity of the analyzed population. In that same year, Pizarro et al. ${ }^{21}$ concluded that absolute and relative adrenal insufficiency was common in children with catecholamine-resistant shock, and with shock not responsive to fluid resuscitation. Menon et al. conducted a very comprehensive work of relative adrenal insufficiency in critically ill children ( $\mathrm{n}=381)$, not necessarily in shock, in seven pediatric tertiary intensive care units in Canada, supporting the concept of relative adrenal insufficiency in critical conditions. ${ }^{22}$ In 2011, the RESOLVE trial ${ }^{23}$ examined children with severe sepsis who received corticosteroids and showed that disease progression was similar to those who did not receive them. The results (mortality, time using inotropes, mechanical ventilation time, organ failure resolution, changes in mortality score, and hospitalization) were similar in children who were treated with and without steroids. Recent studies, including those conducted in developing countries and involving specific pathologies, emphasize the reduction of inotropic agents, without impact on mortality. ${ }^{24,25}$ In 2013, a meta-analysis of trials with a small number of patients showed no benefit attributable to corticosteroids. ${ }^{26}$ Atkins et al. ${ }^{27}$ proposed the lack of evidence of improvement could be due to the fact that children who received corticosteroids had a higher initial mortality risk than those who did not receive them. But in this exact multicentric and retrospective study $(\mathrm{n}=496)$, based on severity stratifications (PERSEVERE and PRISM), no benefits were observed from its use.

Since the first guidelines for the diagnosis and treatment of severe sepsis and septic shock in the 1990s, one of the most controversial issues is the use of corticosteroids as a treatment option, especially in cases of catecholamines resistance. This subject has produced multiple randomized controlled trials in adults, but results are conflicting and a consensus has not been reached. In pediatrics, studies are less abundant, but hydrocortisone is currently recommended for children with septic shock, although there is no clear evidence of its effectiveness. The guidelines of the Surviving Sepsis Campaign $2012^{1}$ stipulated that the use of hydrocortisone should be considered for adult and pediatric septic shock when hypotension does not respond to adequate fluid resuscitation and vasopressors (level $2 \mathrm{C}$ of evidence in adults and $1 \mathrm{~A}$ in pediatrics). The recommendation is also suggested by the American College of Critical Care Medicine. ${ }^{28}$ We must bear in mind that, despite the absence of large randomized controlled trials in children, some information is available from several small studies in the literature, al- though the results are still very unsatisfactory. Thus, in addition to children receiving chronic steroids and children with "classic" adrenal insufficiency, the accumulated evidence does not support a routine use of corticosteroids in children with septic shock.

Guidelines have emerged to standardize the treatment of sepsis and septic shock around the world, also in countries with few resources, reducing costs, morbidity, and mortality. Considering the results of current pediatric studies on the subject, we believe there is a pressing need to update the guidelines, based on the most consistent clinical results. This point-of-view article shows the very limited evidence that is the basis for current guidelines, and thus the need for well-designed studies on the use of corticosteroids in pediatric shock to update future guidance.

\section{References}

1. Dellinger RP, Levy MM, Rhodes A, Annane D, Gerlach H, Opal SM, et al.; Surviving Sepsis Campaign Guidelines Committee including the Pediatric Subgroup. Surviving sepsis campaign: International Guidelines for management of severe sepsis and septic shock: 2012. Intensive Care Med. 2013; 39(2):165-228.

2. Singhi SC, Basal A. Serum cortisol levels in children with acute bacterial and aseptic meningitis. Pediatr Crit Care Med. 2006; 7(1):74-78.

3. Hodes HL, Moloshok RE, Markowitz M. Fulminating meningococcemia treated with cortisone: use of blood eosinophil count as a guide to prognosis and treatment. Pediatrics 1952; 10(2):138-49.

4. Cooperative Study Group. The effectiveness of hydrocortisone in the management of severe infections. JAMA. 1963; 183(6):462-5.

5. Schumer W. Steroids in the treatment of clinical septic shock. Ann Surg. 1976; 184(3):333-41.

6. Bone RC, Fisher CJJ, Clemmer TP, Slotman GJ, Metz CA, Balk RA. A controlled clinical trial of high-dose methylprednisolone in the treatment of severe sepsis and septic shock. N Engl J Med. 1987; 317(11):653-8.

7. Veterans Administration Systemic Sepsis Cooperative Study Group. Effect of high-dose glucocorticoid therapy on mortality in patients with clinical signs of systemic sepsis. N Engl J Med. 1987; 317(11):659-65.

8. Cronin L, Cook DJ, Carlet J, Heyland DK, King D, Lansang MA, et al. Corticosteroids treatment for sepsis: a critical appraisal and meta-analysis of the literature. Crit Care Med. 1995; 23(8):1430-9.

9. Lefering R, Neugebauer EA. Steroid controversy in sepsis and septic shock: a meta-analysis. Crit Care Med. 1995; 23(7):1294-303.

10. Annane D, Bellissant E, Sebille V, Lesieur O, Mathieu B, Raphael JC, et al. Impaired pressor sensitivity to noradrenaline in septic shock patients with and without impaired adrenal function reserve. Br J Clin Pharmacol. 1998; 46(6):589-97.

11. Bollaert PE, Charpentier C, Levy B, Debouverie M, Audibert G, Larcan A. Reversal of late septic shock with supraphysiologic doses of hydrocortisone. Crit Care Med. 1998; 26(4):645-50.

12. Briegel J, Forst H, Haller M, Schelling G, Kilger E, Kuprat G, et al. Stress doses of hydrocortisone reverse hyperdynamic septic shock: a prospective, randomized, double-blind, single-center study. Crit Care Med. 1999; 27(4):723-32.

13. Annane D, Sebille V, Charpentier C, Bollaert PE, François B, Korach JM, et al. Effect of treatment with low doses of hydrocortisone and fludrocortisone on mortality in patients with septic shock. JAMA. 2002; 288(7):862-71.

14. Sprung CL, Annane D, Keh D, Moreno R, Singer M, Freivogel K, et al.; CORTICUS Study Group. Hydrocortisone therapy for patients with septic shock. N Engl J Med. 2008; 358(2):111-24.

15. Beale R, Janes JM, Brunkhorst FM, Dobb G, Levy MM, Martin GS, et al. Global utilization of low-dose corticosteroids in severe sepsis and septic shock: a report from the PROGRESS registry. Crit Care. 2010; 14(3):R102. 
16. Casserly B, Gerlach H, Phillips GS, Lemeshow S, Marshall JC, Osborn TM, et al. Low-dose steroids in adult septic shock results of the Surving Sepsis Campaing. Crit Care Med. 2012; 38(12):1946-54.

17. Patel GP, Balk RA. Systemic steroids in severe sepsis and septic shock. Am J Respir Crit Care Med. 2012; 185(2):133-9.

18. Wong HR, Cvijanovich NZ, Allen GL, Thomas NJ, Freishtat RJ, Anas N, et al. Corticosteroids are associated with repression of adaptive immunity gene programs in pediatric septic shock. Am J Respir Crit Care Med. 2014; 189(8):940-6.

19. Cohen J, Pretorius CJ, Ungerer JPJ, Cardinal J, Blumenthal A, Presneill J, et al. Glucocorticoid sensitivity is highly variable in critically ill patients with septic shock and is associated with disease severity. Crit Care Med. 2016; 44(6):1034-41.

20. Markovitz BP, Goodman DM, Watson RS, Bertoch D, Zimmerman J. A retrospective cohort study of prognostic factors associated with outcome in pediatric severe sepsis: what is the role of steroids? Pediatr Crit Care Med. 2005; 6(3):270-4

21. Pizarro CF, Troster EJ, Damiani D, Carcillo JA. Absolute and relative adrenal insufficiency in children with septic shock. Crit Care Med. 2005; 33(4):855-9.

22. Menon K, Ward RE, Lawson ML, Gaboury I, Hutchison JS, Hebert PC; Canadian Critical Care Trials Group. A prospective multicenter study of adrenal function in critically ill children. Am J Resp Crit Care Med. 2010; 182(2):246-51.

23. Zimmerman JJ, Williams MD. Adjunctive cortocosteroid therapy in pediatric severe sepsis: observations from the RESOLVE study. Pediatr Crit Care Med. $2011 ; 12(1): 2-8$.

24. Valoor HT, Singhi S, Jayashree M. Low-dose hydrocortisone in pediatric septic shock: an exploratory study in a third world setting. Pediatr Crit Care Med. 2009; 10(1):121-5.

25. Hebbar KB, Petrillo T, Fortenberry JD. Adrenal insufficiency and response to corticosteroids in hypotensive critically ill children with cancer. J Crit Care. 2012; 27(5):480-7.

26. Menon K, McNally D, Choong K, Sampson M. A systematic review and meta-analysis on the effect of steroids in pediatric shock. Pediatr Crit Care Med. 2013; 14(5):474-80.

27. Atkinson SJ, Cvijanovich NZ, Thomas NJ, Allen GL, Anas N, Bigham MT, et al. Corticosteroids and pediatric septic shock outcomes: a risk stratified analysis. PLoS ONE. 2014; 9(11):e112702.

28. Brierley J, Carcillo JA, Choong K, Cornell T, Decaen A, Deymann A, et al. Clinical practice parameters for hemodynamic support of pediatric and neonatal septic shock: 2007 update from the American College of Critical Care Medicine. Crit Care Med. 2009; 37(2):666-88. 